\title{
Possible Multiple Sources of the Strong 1117 Po Plain Earthquake, Inferred from the Plio-Quaternary Evolution of the Northern Adriatic Area
}

\author{
Enzo Mantovani ${ }^{*}$, Giuliano Brancolini ${ }^{2}$, Daniele Babbucci ${ }^{1}$, Caterina Tamburelli ${ }^{1}$, Marcello Viti ${ }^{1}$ \\ ${ }^{1}$ Dipartimento di Scienze Fisiche, della Terra e dell'Ambiente, Università di Siena, Siena, Italy \\ ${ }^{2}$ Istituto Nazionale di Oceanografia e Geofisica Sperimentale-OGS, Trieste, Italy \\ Email: *enzo.mantovani@unisi.it
}

How to cite this paper: Mantovani, E., Brancolini, G., Babbucci, D., Tamburelli, C. and Viti, M. (2021) Plain Earthquake, Inferred from the Plio-Quaternary Evolution of the Northern Adriatic Area. International Journal of Geosciences, 12, 381-403. https://doi.org/10.4236/ijg.2021.124020

Received: March 3, 2021

Accepted: April 26, 2021

Published: April 29, 2021

Copyright $\odot 2021$ by author(s) and Scientific Research Publishing Inc. This work is licensed under the Creative Commons Attribution International License (CC BY 4.0).

http://creativecommons.org/licenses/by/4.0/

\section{(c) (i) Open Access}

\begin{abstract}
The strongest documented seismic disaster ever occurred in the Po Plain area (January 3, 1117, $\mathrm{M}=6.5$ ) involved significant damage over a large zone. The genetic mechanism of such an event, most probably caused by more than one earthquake, is still an object of debate. Above all, the sources so far proposed cannot account for significant features of the observed macroseismic field. In this work, we suggest that the damage in the Verona zone was caused by the activation of a fault in the Lessini tectonic district, while damage in the central Po Plain may be related to a thrust fault located beneath the Giudicarie belt. The effects felt in northern Tuscany might derive from the seismic activation of the presumed SW-ward buried prolongation of the Giudicarie fault. The presence of such transpressional lithospheric discontinuity in the Adriatic domain since the upper Miocene and its reactivation (Pliocene-Pleistocene) as a thrust zone is mainly suggested by an accurate analysis of the observed deformation pattern in the central Mediterranean region. The proposed Giudicarie source may also help to explain the damage observed in the central Po Plain on December 25, 1222, which is not compatible with the seismic sources so far proposed.
\end{abstract}

\section{Keywords}

Northern Adriatic Tectonics, Po Plain, Giudicarie Thrust Zone, January 3, 1117 Earthquake Sources

\section{Introduction}

On January 3, 1117, considerable damage occurred in northern Italy (Figure 1), 
involving a large part of the Po Plain, possibly affecting northernmost Tuscany (Figure 2(A), e.g., [1]-[6]). Several attempts have been made at identifying the possible sources of that event (Figure 2(B)), but none of the proposed sources can account for the full observed macroseismic field. The Italian seismic catalogue [7] tentatively assumes a single earthquake, located near the town of Verona, but this hypothesis does not explain the damages that occurred in the central Po Plain. The effects felt in northern Tuscany are ascribed to an independent event. The DISS database (e.g., [8] [9]) suggests that the Verona source may relate to a Mesozoic extensional fault roughly oriented ENE/WSW, recently reactivated as a reverse fault. This hypothesis is mainly based on the study of the morphology and drainage pattern of the Adige and Mincio rivers in the epicentral zone [10].

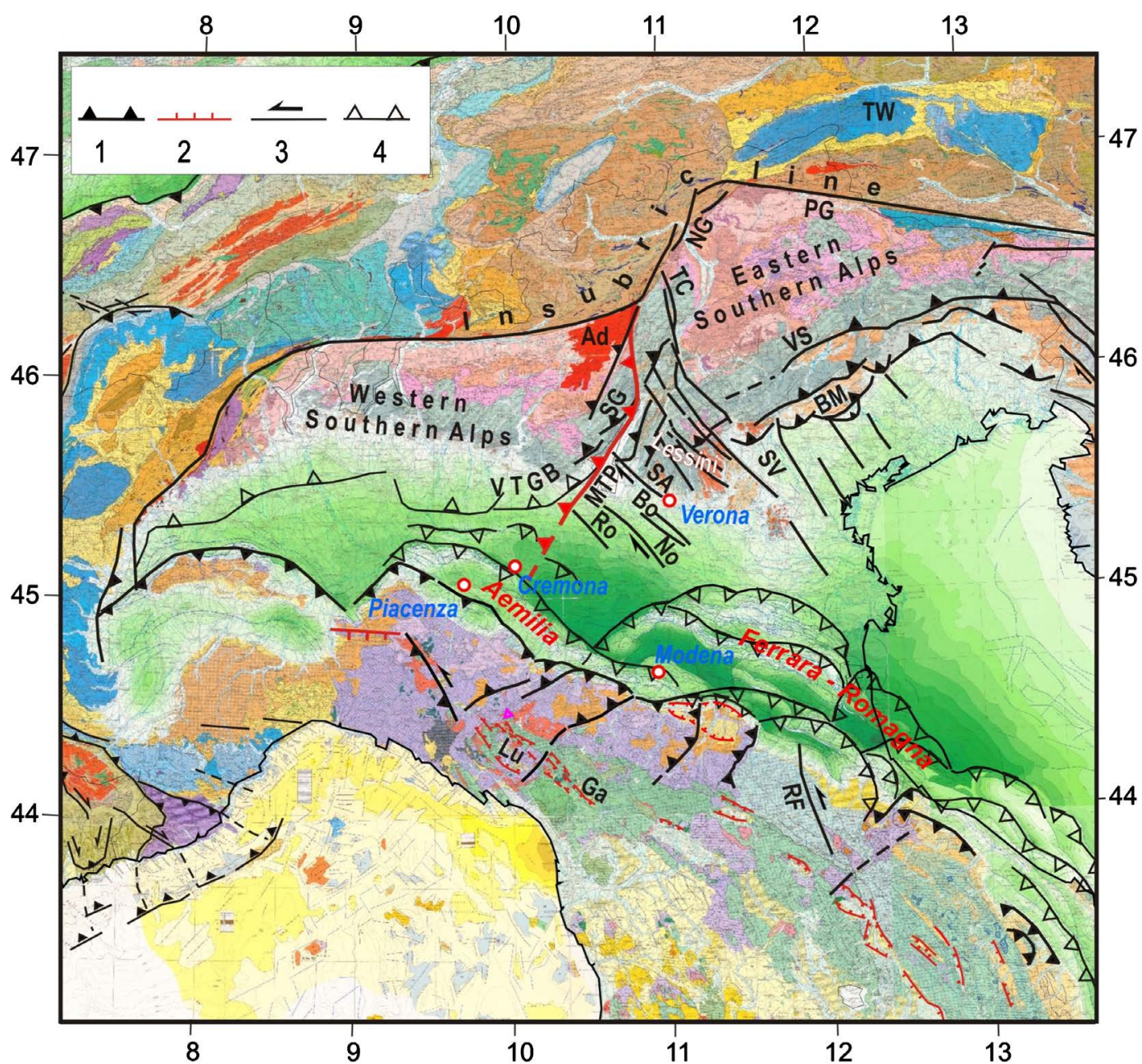

Figure 1. Tectonic sketch of the Padanian zone and surrounding belts (modified after [11]). 1, 2, 3, 4) Main compressional, extensional, transcurrent features and fronts of buried folds (e.g. [12]-[17]). Ad = Adamello intrusion; $\mathrm{BM}=$ Bassano-Montello front; $\mathrm{Bo}=$ Bovolone fault; $\mathrm{Ga}=$ Garfagnana trough; Lu = Lunigiana trough; MTP = Margin of the Early-Middle Jurassic Trento platform; NG = North Giudicarie line; No = Nogara fault; PG = Pusteria-Gail line; RF = presumed Romagna fault; Ro = Rodigo fault; SA = Sant'Ambrogio fault; SG = South Giudicarie line; SV = Schio-Vicenza fault; TC = Trento-Cles fault; TW = Tauern Window; VS = Valsugana front; VTGB = Val Trompia-Giudicarie belt. 

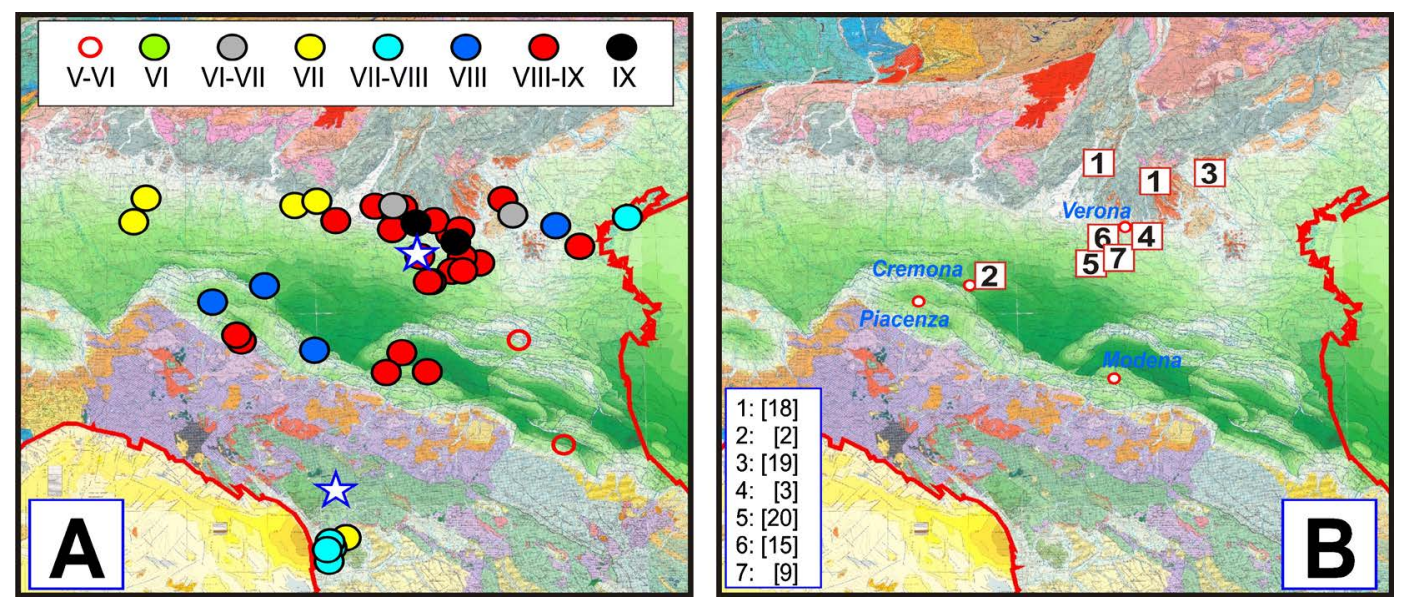

Figure 2. (A) Intensity values related to the January 3, 1117 event in the Po Plain and northern Tuscany [6] reported on the Structural map of Italy [13]. The stars indicate the epicentral locations of the Padania and Tuscany earthquakes suggested by the seismic catalogue ([4] [7]). (B) Locations of the proposed seismic sources of the January, 3, 1117 earthquakes [20].

Alternative hypotheses have been advanced to account for the damage observed in the Verona zone (Figure 2(B)). Some authors [2] [18] [19] [21] suggest the possible role of reverse faults aligned with the Bassano-Montello compressional front (Figure 1), respectively located west (Lessini) and east (Thiene-Bassano) of the Schio-Vicenza fault system. Other epicentral locations, spanning from Lake Garda to the Verona zone, are suggested by other authors (e.g., [3]). [15] and [20] suggest two faults in the Lessini zone (Nogara and S. Ambrogio). [22] proposes a source in the Lessini district, although they consider that the January 3 , 1117 event remains one of the most problematic cases, both for the location and estimate of the effects. These authors suggest that the Lessini structure has undergone an articulated anticlinal uparching, with the formation of small blocks affected by differential uplift and tilting [23] [24]. A roughly N-S direction of maximum compressional stress is inferred from focal mechanisms by [25]. The presence of seismogenetic faults in the Lessini district is also suggested by other authors (e.g., [15] [20] [26] [27]).

To explain the damages observed in the central Po Plain [2] has proposed a second source involving a thrust fault located along the Emilian buried folds (Piadena anticline, near the town of Cremona, Figure 2(B)). This author tentatively correlates the anomalies of the Po and Oglio rivers and the migration toward the south of the Po river during historical time with the recent uplift of the Piadena anticline. However, it must be considered that during the Middle and Upper Pleistocene, tectonic activity in the Piadena anticline has been characterized by a general decreasing trend [28]. This is shown by the strong decrease of the uplift rates from $1.20 \pm 0.12 \mathrm{~mm} / \mathrm{yr}$ (in the $1.50-1.25 \mathrm{Myr}$ interval) to $0.06 \pm$ $0.05 \mathrm{~mm} / \mathrm{yr}$, in the last $0.45 \mathrm{Myr}$, but it is also well documented on a more regional scale ([29] and reference therein). The uplift rate values are systematically one order of magnitude lower compared to the sedimentation rates in the same area. This evidence suggests that the development of the Piadena anticline has 
become very elusive since the Middle Pleistocene (e.g. [28]). It must be underlined that [2] admits that the source he proposes cannot account for the damages observed in the Piacenza, Parma and Modena zones.

As regards the event in northern Tuscany, only a few observed intensity points are available (Figure $2(\mathrm{~A})$ ), which implies a considerable uncertainty in the location of the epicentre and focal depth (e.g., [3] [5]). The CFTI catalogue [4] indicates an epicenter in the Garfagnana zone, which is north of the observed maximum damage (Figure 2(A)), while the CPTI catalogue ([7]) provides a generic epicenter in the Monti Pisani zone. Most authors (e.g., [4]) claim that the distance (about $180 \mathrm{~km}$ ) between the worst damage that occurred in Tuscany and the epicentral zone of the concomitant earthquake in the Po Plain, combined with the lack of information on damage between the two areas, can only be explained by the occurrence of an earthquake distinct from the one that caused the effects in the Po Plain.

This work describes an attempt to identify alternative seismic sources able to better account for the macroseismic field observed in the Po Valley and Tuscan zones.

\section{Activation of Major Fault Zones in the Northern Adriatic Domain since the Upper Miocene}

In the period considered, two major decoupling zones developed in the northern Adriatic domain (e.g., [30] [31] [32]). The first is the Giudicarie discontinuity (Figure 3), an old thrust fault that was reactivated as a sinistral transpressional shear zone around the Tortonian (e.g., [14] [33] [34]). The Neogene Giudicarie fault system has been interpreted as a lateral ramp (e.g., [35] [36]), but this hypothesis cannot easily be reconciled with major evidence on the Neogenic deformation pattern in the central Mediterranean region, as extensively argued in previous papers (e.g., [17] [31] [32]). Furthermore, lateral ramps alone cannot explain the complex features and the kinematics of the South Giudicarie belt. There seems to be an almost unanimous agreement on the fact that the Neogene kinematics of the Giudicarie system is transpressive (e.g., [14] [33] [37] [38]).

The other major decoupling zone is the Schio-Vicenza fault system (SV in Figure $3(\mathrm{C})$ ), an old weakness zone of the northern Adriatic foreland that was reactivated as a sinistral strike-slip fault around the Late Messinian ([39] [40]). The geodynamic context and the tectonic evolution that led to the development of such discontinuity (Figure 3) have been discussed in a number of papers (e.g., [30] [31] [32] [41] [42] [43] [44] [45] and references therein).

In the Middle Miocene (Figure 3(A)), buoyancy forces in the Adria-Eurasia collision zone (Alps) are shown to have strongly counteracted to any further crustal shortening, due to the large amount of light upper crustal material accumulated during the long phase of plate convergence (e.g., [46]). Such critical situation was overcome by exploiting the presence of a weak lateral constraint in the Carpathian-Pannonian area (e.g., [47] [48] and references therein, [42] [49]), which favoured the eastward expulsion of wedges lying North of the Pusteria-Gail 


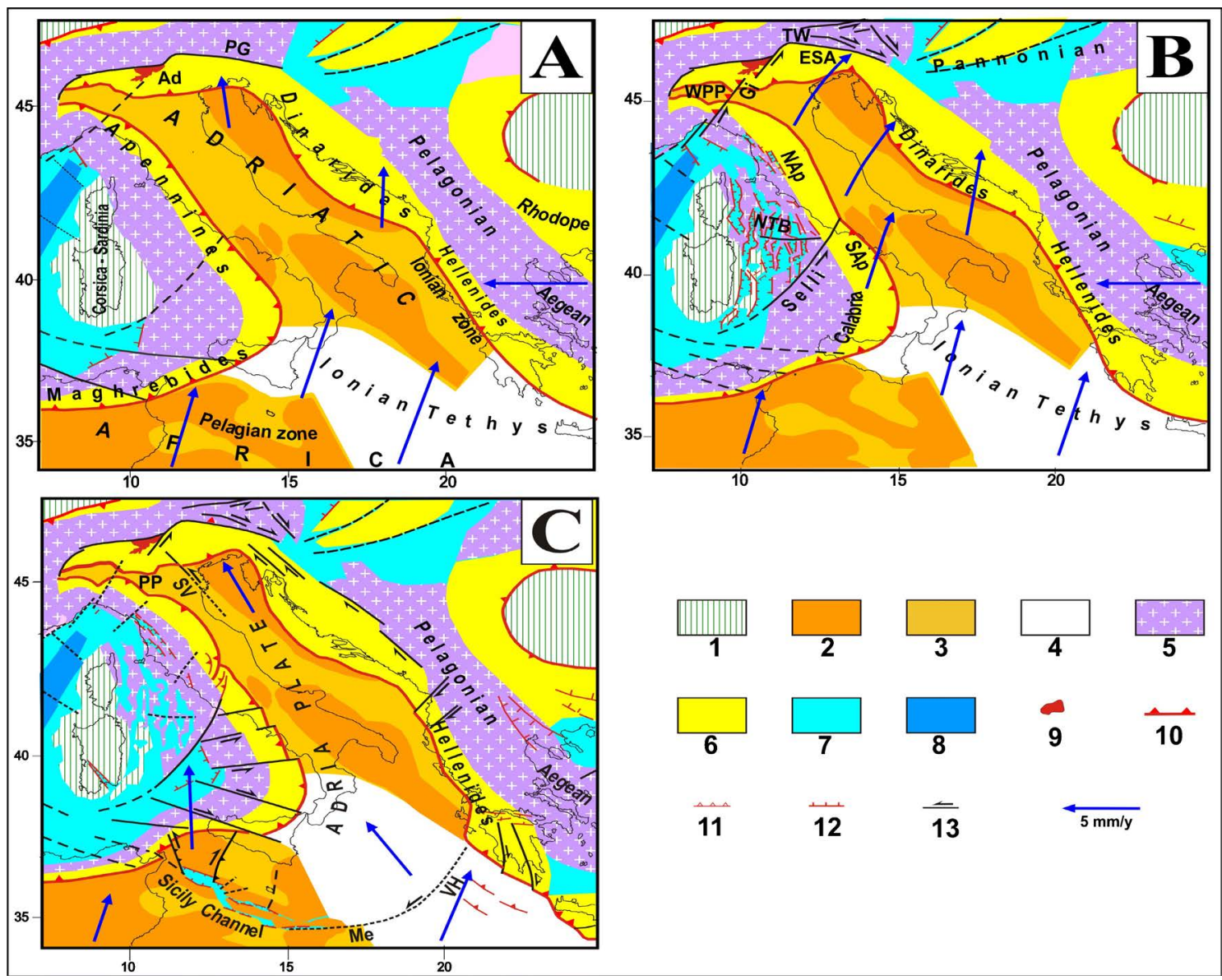

Figure 3. Proposed evolutionary reconstruction of the central Mediterranean area ([30] [32] [41]). (A) Middle Miocene. The Adriatic promontory collides with the European domain. Blue arrows indicate the proposed kinematic pattern (e.g., [50]). Ad = Adamello intrusion; PG = Pusteria-Gail line. (B) Upper Miocene. After the reactivation of the Giudicarie fault system (Gi), the northern Adriatic promontory undergoes a NE ward motion and clockwise rotation, releasing its previous internal deformation. The divergence between that promontory and the stable Corsica-Sardinia block induces crustal extension in the interposed Alpine-Apennine belt, with the formation of the Northern Tyrrhenian basin (NTB). ESA = Eastern Southern Alps; NAp, SAp = Northern and Southern Apennines; TW = Tauern Window; WPP = Western Po Plain. (C) Pliocene. A large part of the Adriatic promontory (Adria) decouples from Africa, by major discontinuities in the Pelagian and Ionian zones, the Sicily Channel-Medina (Me)-Victor Hensen (VH) fault systems, and from its Po Plain sector (PP), by the Schio-Vicenza (SV) fault system. 1) Continental Eurasian domain; 2, 3) continental and thinned continental African and Adriatic domains; 4) old oceanic domains; 5) Alpine belt; 6) other orogenic belts; 7, 8) tectonically thinned and oceanized zones; 9) Adamello pluton; 10) outer fronts of belts; 11, 12,13) compressional, extensional and transcurrent features.

line (PG in Figure 3(A)). In the wake of such extrusion extensional deformation developed, with the exhumation of the Tauern window complex (TW in Figure 3(B), e.g., [37] [51] [52]). This lateral escape of orogenic material favoured the roughly NNE-ward displacement of the main Adriatic plate (estimated in about $10-12 \mathrm{~km}$, [14] [33] [53] [54]), after decoupling from its northwestern protuberance, which was accommodated by the left-lateral transpressive reactivation of the Giudicarie fault system (e.g., [14] [34] [37] [55]). This hypothesis ([30] [31] [32] [41]) is consistent with the fact that since the Tortonian the shortening rate in the Alpine sector lying west of the Giudicarie fault system underwent a 
considerable slowdown (e.g., [14] [56]), while thrusting mostly occurred East of the Giudicarie fault system (Valsugana thrust front). During this phase, transpressional deformation developed in the Giudicarie and Val Trompia belts (e.g., [14] [38]). Other information about the timing of this major decoupling mechanism may be inferred from the exhumation history of the Adamello intrusion, in particular the fact that such process was characterized by a phase of maximum activity around the Tortonian (8 - $9 \mathrm{My}$, [57]).

The displacement of the northern Adriatic domain caused lowering of its subducted margin (buried below the Apennine belt), as tentatively reconstructed in Figure 4.

The subsequent subsidence of this structure with respect to the domain lying west of the Giudicarie discontinuity caused the onset of a pronounced vertical throw (Figure 5(B)).

The presence of a greater dip in the eastern Po Plain Adriatic monocline, with respect to the western domain (underlying the central Po Plain) is testified by cross sections (Mesozoic units in Figure 6) and is suggested by some authors (e.g., [8] [58] and references therein). A different structural setting in the eastern and western Po Plain is evidenced by other authors (e.g., [59] [60]), which indicate the Giudicarie discontinuity as a possible boundary between the two regions.

The other decoupling discontinuity in the northern Adriatic area, the SchioVicenza (SV) fault system, developed around the Messinian (e.g., [39] due to the
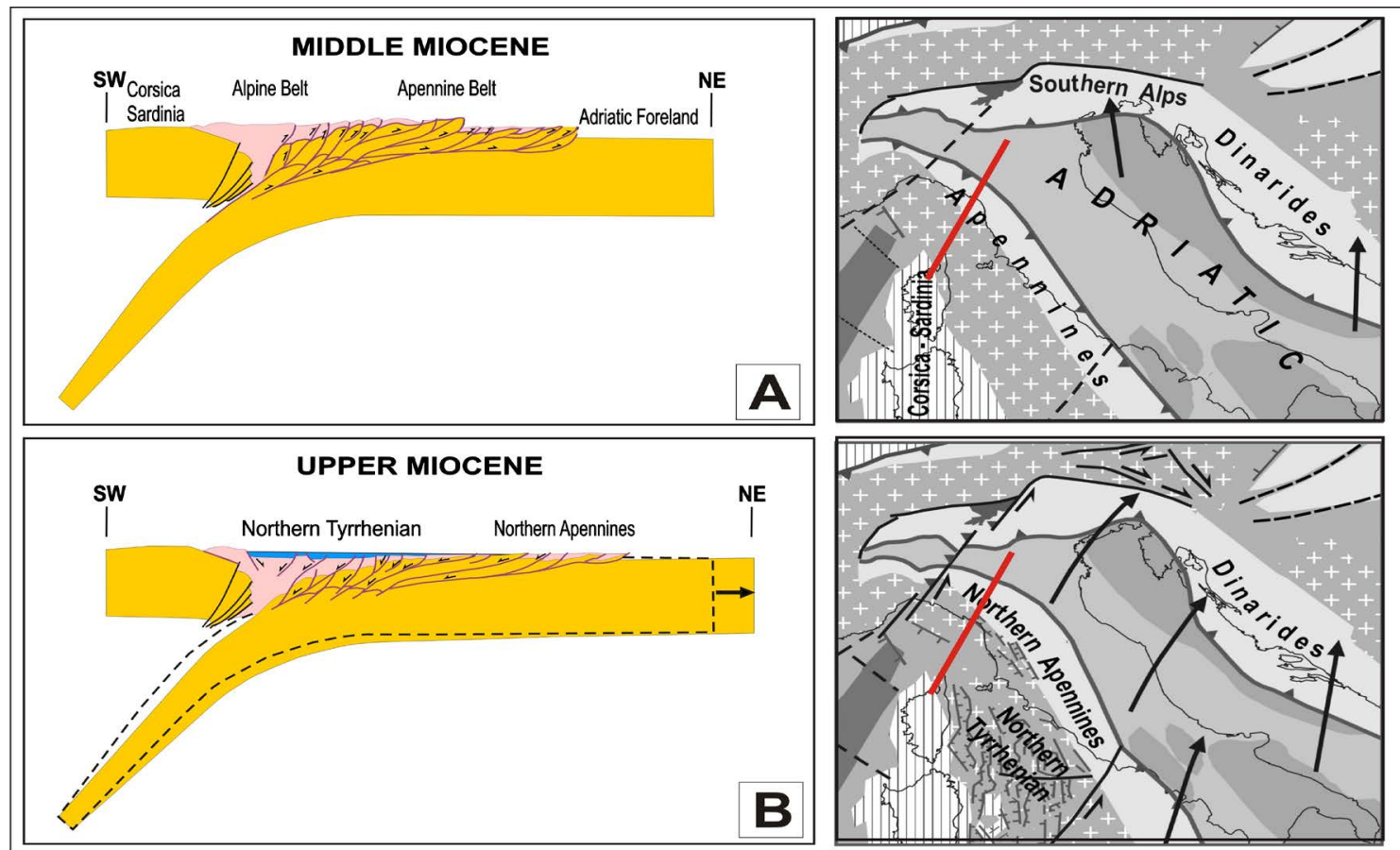

Figure 4. Tentative reconstruction of the lowering that the Adriatic slab may have undergone in response to the NE ward displacement of its shallowest domain. (A) Middle Miocene slab configuration along the section through the northern Apennines (red trace in the map). (B) The NE to NNE ward displacement of the Adria plate causes lowering of its subducted margin, forming a pronounced offset at the Giudicarie fault (Figure 5(B)). The dashed line indicates the presumed Middle Miocene configuration of the slab. 

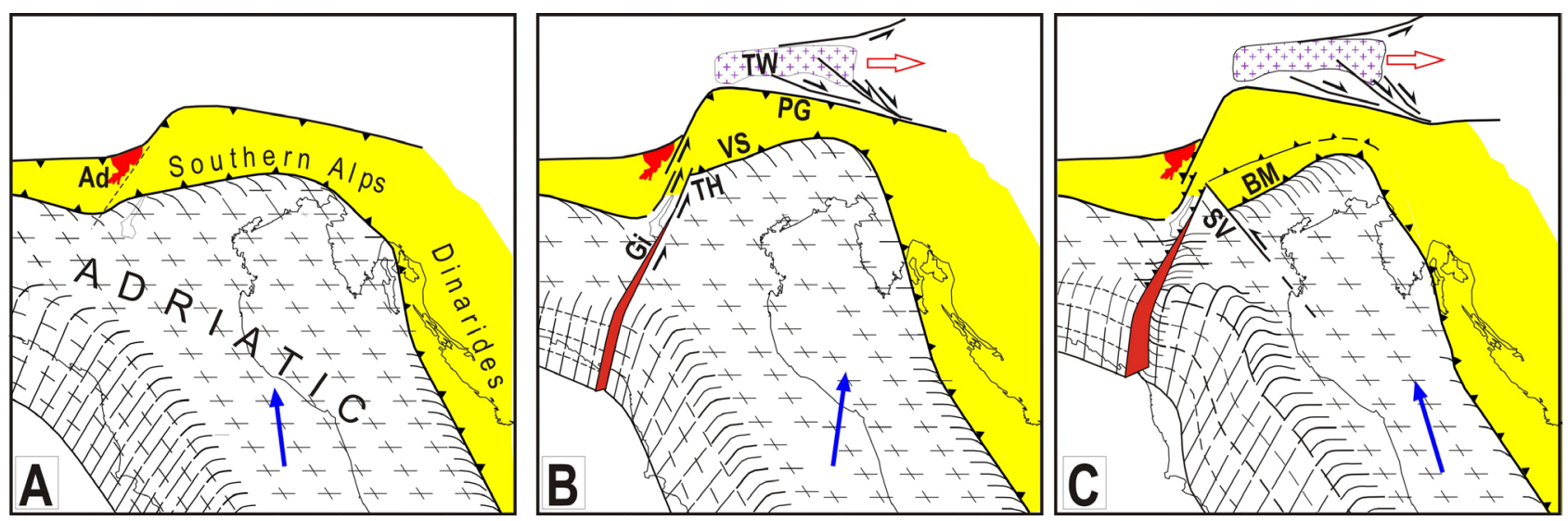

Figure 5. Perspective view of the Adriatic domain, evidencing the major fault systems that developed in this continental structure. (A) Middle Miocene: the Adriatic/African promontory moves roughly Northward (blue arrow), causing thrusting along the Alps. The red spot indicates the Adamello intrusion (Ad). (B) Upper Miocene: the lateral escape of Alpine wedges creates a weak boundary zone (Tauern window $=\mathrm{TW}$ ) along the northeastern Adriatic front, inducing shear stress at an old Adriatic weak zone that reactivates as a left lateral transpressive fault system (Giudicarie $=\mathrm{Gi}$ ). This fault allows the Adriatic promontory to decouple from its northwestern protuberance and move NE ward. TH = Trento Horst; VS = Valsugana front; PG = Pusteria-Gail line. $(\mathrm{C})$ Pliocene-Quaternary: the Adria plate, no longer connected with Africa (Figure 3), tends to move roughly NNW ward, underthrusting the Eastern Southern Alps. The strong resistance encountered by the Adriatic plate in the central Alps (Trento Horst and Adamello intrusion) required the activation of a major strike-slip fault system (Schio-Vicenza $=$ SV) that allowed the main Adriatic plate to decouple from its Po Plain sector. Due to the compressional regime induced in this zone by the Adria plate, the Giudicarie discontinuity (characterized by a vertical offset) becomes a thrust zone, where the eastern Po Plain Adria domain underthrusts the western one. $\mathrm{BM}=$ Bassano-Montello front.

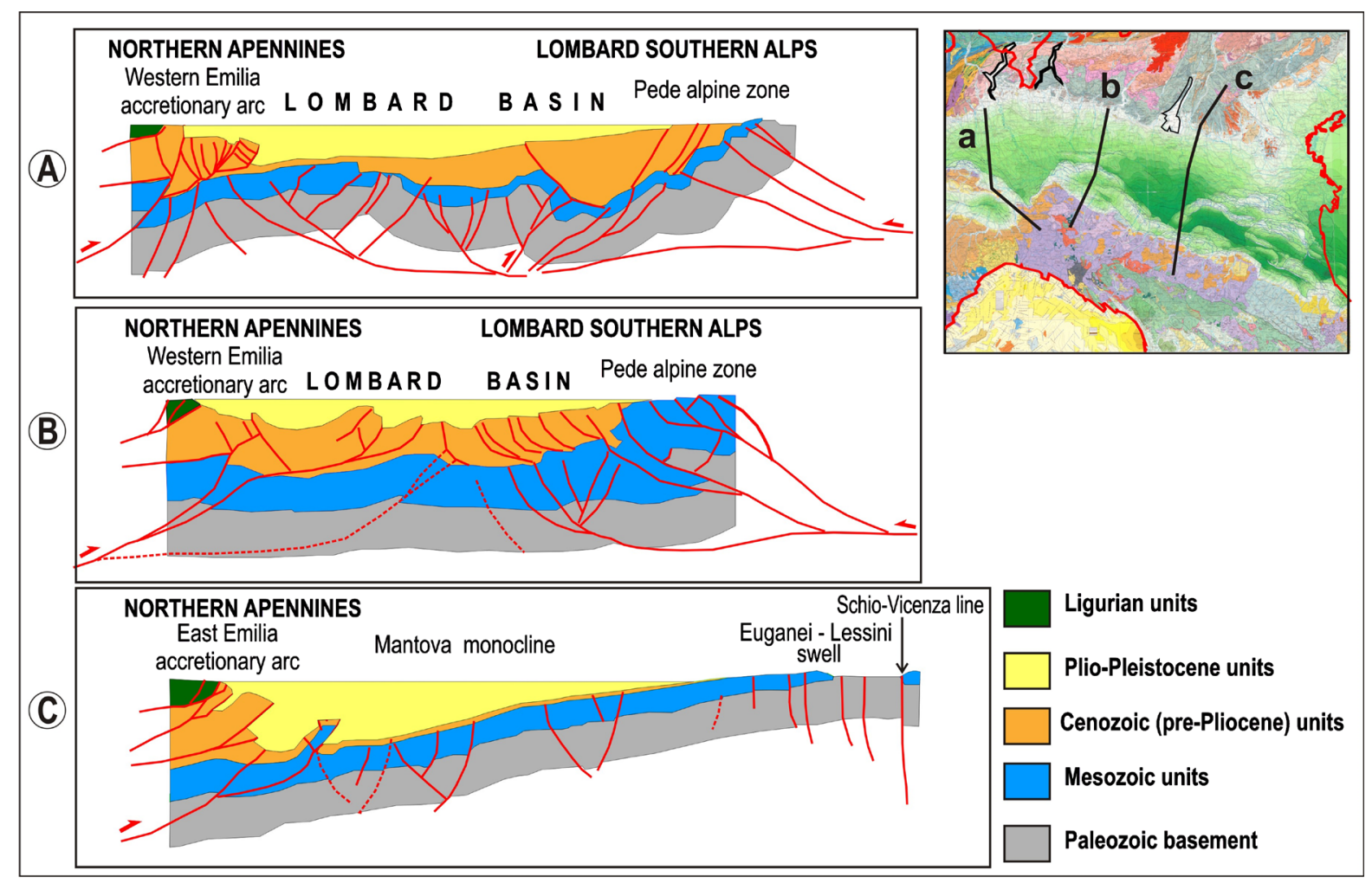

Figure 6. Cross-sections in the Po Plain region, tracks as plotted in the map [62]. The different deeps of the Mesozoic layer lying west (A) and (B) and East (C) of the Giudicarie belt are compatible with the presumed vertical throw at that discontinuity (See text). 
reactivation of an old weakness zone in the Adriatic foreland (e.g., [61]).

This event developed in the framework of a major tectonic reorganization in the whole central Mediterranean region [30] [31] [32] [41], which involved a decoupling of the Adria plate from Africa, by the Sicily Channel-Medina-VictorHensen fault zone (Figure 3(C)), and from the western Po Plain domain, by activating the SV fault system which was more suitably oriented for the NNWward motion trend of the newly independent Adria microplate (Figure 3(C)). The peculiar location of the SV decoupling fault was mainly influenced by the fact that in the Miocene (Figure 3(B)) the resistance against the northward motion of the Adriatic plate was considerably lower in the eastern Southern Alps, facing the Tauern window (Figure 3(B)) than in the central Alps, where more rigid structures were located, such as the Adamello intrusion and the Trento Horst (Figure 5(B)) well connected with the underlying basement (Figure 3(C) and Figure $5(\mathrm{C})$ ). The shear stress induced by such different resistances in front of the Adriatic indenter led to the activation of the SV fault system (e.g., [14] [31] [34]). The hypothesis that the Adamello intrusion acted as an undeformable body has been suggested by some authors (e.g., [63]). The important role that this intrusion may have played in the evolution of the northern Adriatic zone is suggested by the locations of the two main decoupling fault systems (Giudicarie and SV, Figure 3). In the Upper Miocene, the Giudicarie fault activated just East of the Adamello body, which allowed the Adria domain (moving roughly North to NNE-ward) to avoid the resistance of that strong structure (Figure 3). In the Messinian, the SV fault system activated just East of the Adamello to bypass that obstacle. Another evidence in this regard may be the fact that the Lessini foreland Adriatic outcrop lay just in front of the Adamello magmatic body. The above interpretation is consistent with the fact that exhumation of the Adamello intrusion has considerably slowed down or halted in the last $6 \mathrm{My}$ [57], that is when the motion trend of Adria considerably changed, after the activation of the SV fault system.

Since the formation of the SV decoupling fault system, the main Adria domain, lying East of that fault, has moved roughly $\mathrm{N}$ to NNW ward by underthrusting the eastern Southern Alps, while the western domain, i.e. the Po Plain, lying between the SV and Giudicarie fault systems, has faced the central Alps (Adamello intrusion) and the Giudicarie belt (Figure 1). This convergence can explain why a part of the Adriatic foreland is now outcropping in the Lessini zone, characterized by transpressional faults [15] [27], and why compressional deformations are recognized in the Giudicarie belt (e.g., [20]) and the underlying crust (Figure 5 and Figure 7). Due to the different vertical behaviors of the Adriatic domains lying East and West of the Schio-Vicenza fault, such discontinuity has developed a vertical throw, progressively growing northward (e.g., [40]).

The hypothesis that the eastern Po Plain domain is underthrusting the western domain, roughly beneath the Giudicarie belt (Figure 7), may find support in geodetic evidence of the present vertical displacement field (Figure 8), which 

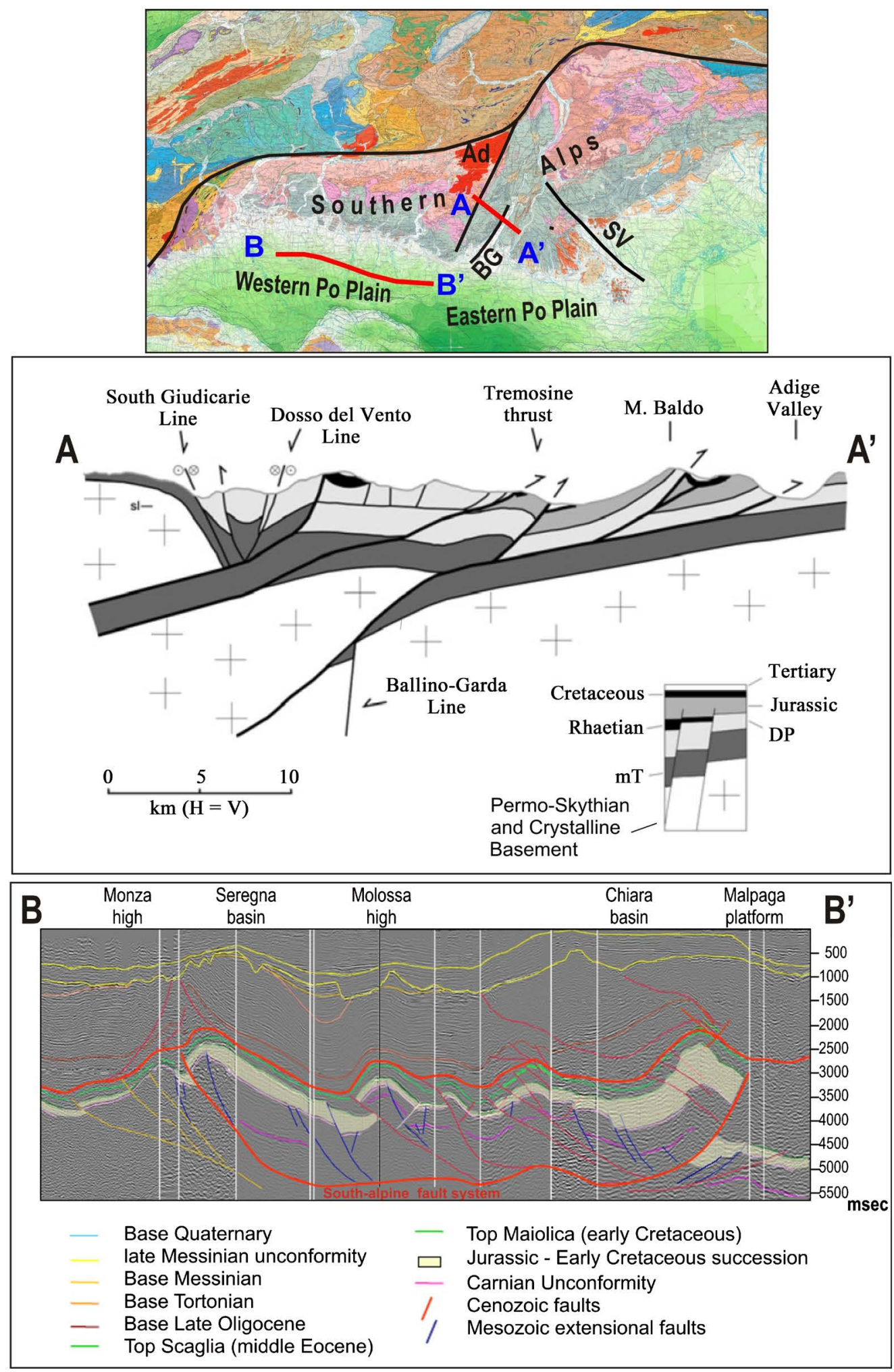

Figure 7. Structural setting along two sections (red lines) beneath the Giudicarie belt (A-A', [53]) and the western Po Plain domain (B-B'). Ad = Adamello intrusion; BG = Ballino-Garda fault; $\mathrm{SV}=$ Schio-Vicenza fault system. The light band in the section B-B' indicates the Cretaceous succession, whose strong deformation evidences horizontal shortening and a possible underthrusting process below the Giudicarie belt (Malpaga). Depth in msec (Modified after [64]). 


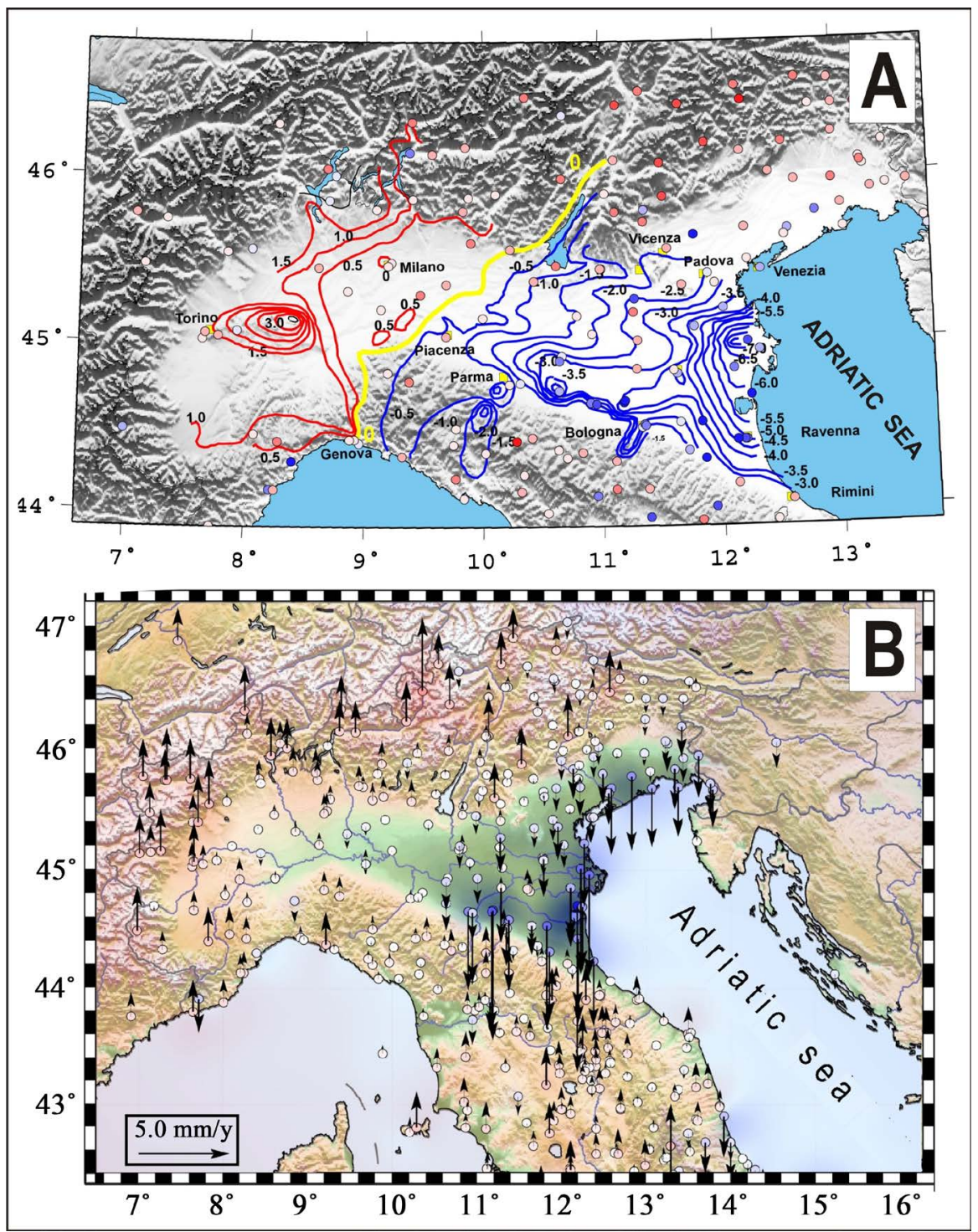

Figure 8. (A) Vertical movements measured in the period 1897-1957 by terrestrial geodetic techniques [65]. Red and blue isolines respectively relate to upward and downward motions (mm/y), after [66]. (B) Vertical kinematic field in the Po Plain based on GPS observations [67] [68].

indicates uplift in the overthrusting domain (western Po Plain) and intense subsidence in the underthrusting domain (eastern Po Plain). This kinematics is indicated by terrestrial techniques (Figure $8(\mathrm{~A})$ ), which suggest uplift of $1-3$ $\mathrm{mm} / \mathrm{y}$ in the western Po Plain area and subsidence rates, up to $7 \mathrm{~mm} / \mathrm{y}$, in the eastern one. This last evidence [65] is particularly significant since such measurements have been carried out in a period (1897-1957) when the effects of anthropic activities were more limited.

Subsidence in the eastern Po Plain is mostly attributed to a long-term effect (about $1 \mathrm{~mm} / \mathrm{y}$ ), due to the compaction of Holocene sediments [69] [70], and to a recent and more significant effect (up to about $10 \mathrm{~mm} / \mathrm{y}$ ), induced by anthropic activities (e.g., [68] [71]). Considering that long-term and short-term subsi- 
dence may also affect (even if with lower rates) the western Po Plain, the almost null vertical motion indicated by GPS data (Figure 8(B)) may imply that such zone is undergoing a contemporaneous uplift of a few $\mathrm{mm} / \mathrm{y}$. [69] suggests that vertical motions in this area are mainly influenced by the retreat of the Adriatic subduction. However, the implications of that driving force can hardly be reconciled with the major Neogene tectonic processes recognized in the central Mediterranean region (e.g., [17] [30] [31] [32]).

\section{Present Geodynamic/Tectonic Setting and Possible Sources of the 1117 Earthquakes}

The evolutionary history of the study area suggests that tectonic activity in the northern Adriatic region is driven by the northward motion of the Adriatic plate with respect to Europe (e.g., [30] [31] [32] [41]). Displacement of the Adria domain lying East of the Schio-Vicenza fault system is triggered by major transpressional and compressional earthquakes in the Eastern Southern Alps and Northern Dinarides (Figure 9).

The Po Plain sector of Adria moves coherently with the main plate (from which it is only partially decoupled by the SV fault), but its motion is slower, due to the presence of rigid bodies in the Central Alpine belt, as discussed earlier. Displacements of this Po Plain domain are triggered by significant earthquakes

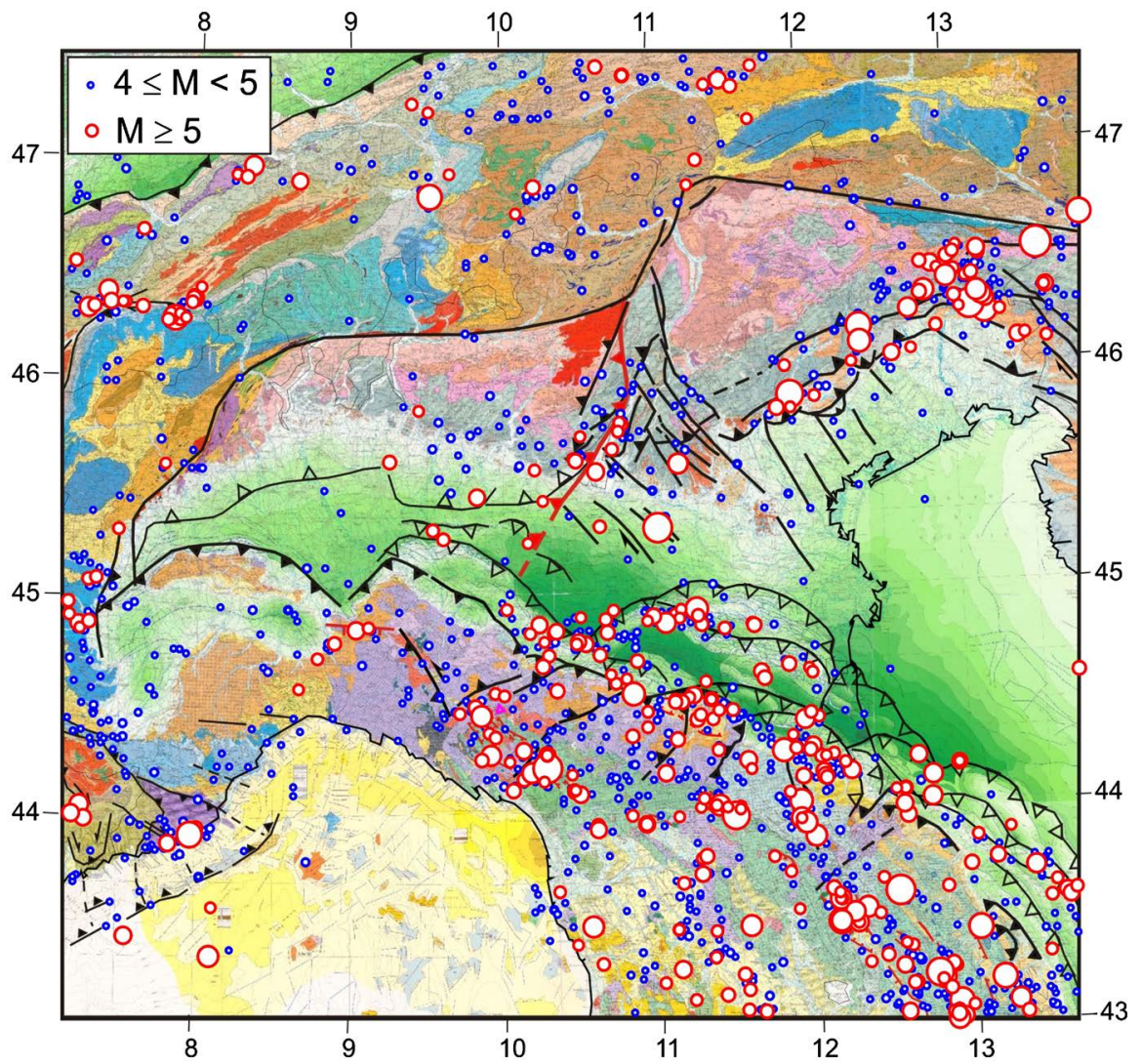

Figure 9. Major earthquakes occurred in the study area since 1000 A.D. [7] [72] [73] reported on the tectonic sketch in Figure 1. 
along the dextral transpressional faults recognized in the Lessini district (e.g., [15] [27]), as the Valle D'Illasi event in $1891(\mathrm{M}=5.9)$, as well as by the activation of thrust faults beneath the Giudicarie belt (Figure 5(C) and Figure 7), which might well have occurred on January 3, 1117.

On the basis of the above considerations, we propose that the 1117 destruction was produced by three almost simultaneous earthquakes, one located in the Lessini district, another in the thrust fault presumably lying below the Giudicarie belt and a third one in the southward buried prolongation of the Giudicarie lithospheric discontinuity, underlying northern Tuscany.

To tentatively identify the location and hypocentral parameters of the 3 sources that best account for the observed macroseismic field (Figure 2), we have adopted the following strategy. For the source in the Lessini zone ( $\mathrm{L}$ in Figure 10) we have assumed the location and hypocentral parameters provided by the seismic catalogue [7]. In the central Po Plain, we have taken into account two possible segments (G1 or G2 in Figure 10) of the thrust fault lying below the Giudicarie belt. For the Tuscany event, the possible sources are located along the buried sector of the proposed lithospheric discontinuity (T1 or T2 in Figure 10).

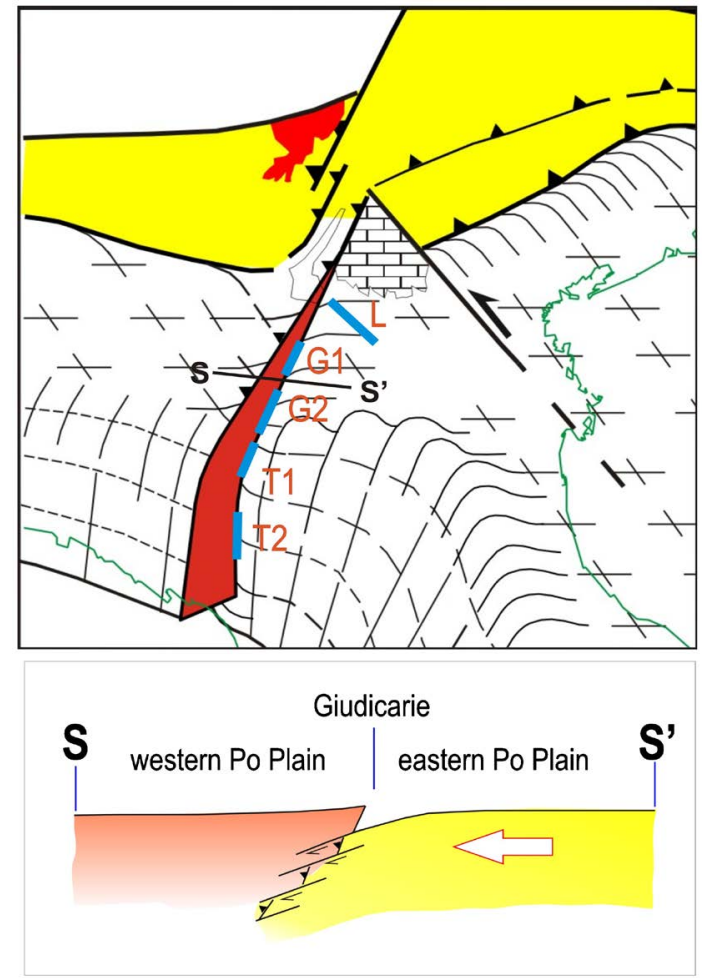

Figure 10. (Top) Location and hypocentral parameters of the seismic sources used to determine the macroseismic fields shown in Figure 11 . $\mathrm{L}=$ Lessini fault, $\mathrm{M}=6.5$, focal depth $=10 \mathrm{~km}$ [7], G1 = Northern sector of the Giudicarie thrust fault, $\mathrm{M}=6.5$, depth = $15 \mathrm{~km} ; \mathrm{G} 2=$ Southern sector of the Giudicarie thrust fault, $\mathrm{M}=6.7$, depth $=25 \mathrm{~km}$; $11=$ northern sector of the buried tear fault under northern Tuscany, $M=6.5$, depth $=30 \mathrm{~km}$; $\mathrm{T} 2=$ southern sector of the buried tear fault under Northern Tuscany, $\mathrm{M}=6.7$, depth $=$ $50 \mathrm{~km}$. (Bottom) Section evidencing the proposed thrust fault system beneath the Giudicarie belt. 
Then, we have calculated the intensity values (represented by isolines) related to different sets of 3 sources, by using the Magnitude-Intensity relationship given by Rovida et al. (2019) [7] and the attenuations laws suggested by Decanini and Mollaioli (1997) [74].

The results obtained (Figure 11) indicate that, among the solutions considered, the best agreement between the computed intensities and the observed ones is obtained by taking into account the three sources identified by L, G2 and T2 (Figure 11(D)). It can be noted that such solution could even account for the relatively high intensity values felt in the Modena zone, since such zone is roughly located where the combined effects of the three sources considered (mainly the VII and VII-VIII intensity values) may produce a local high in the macroseismic field.

The hypothesis that the January 3,1117 disaster was caused by the activation
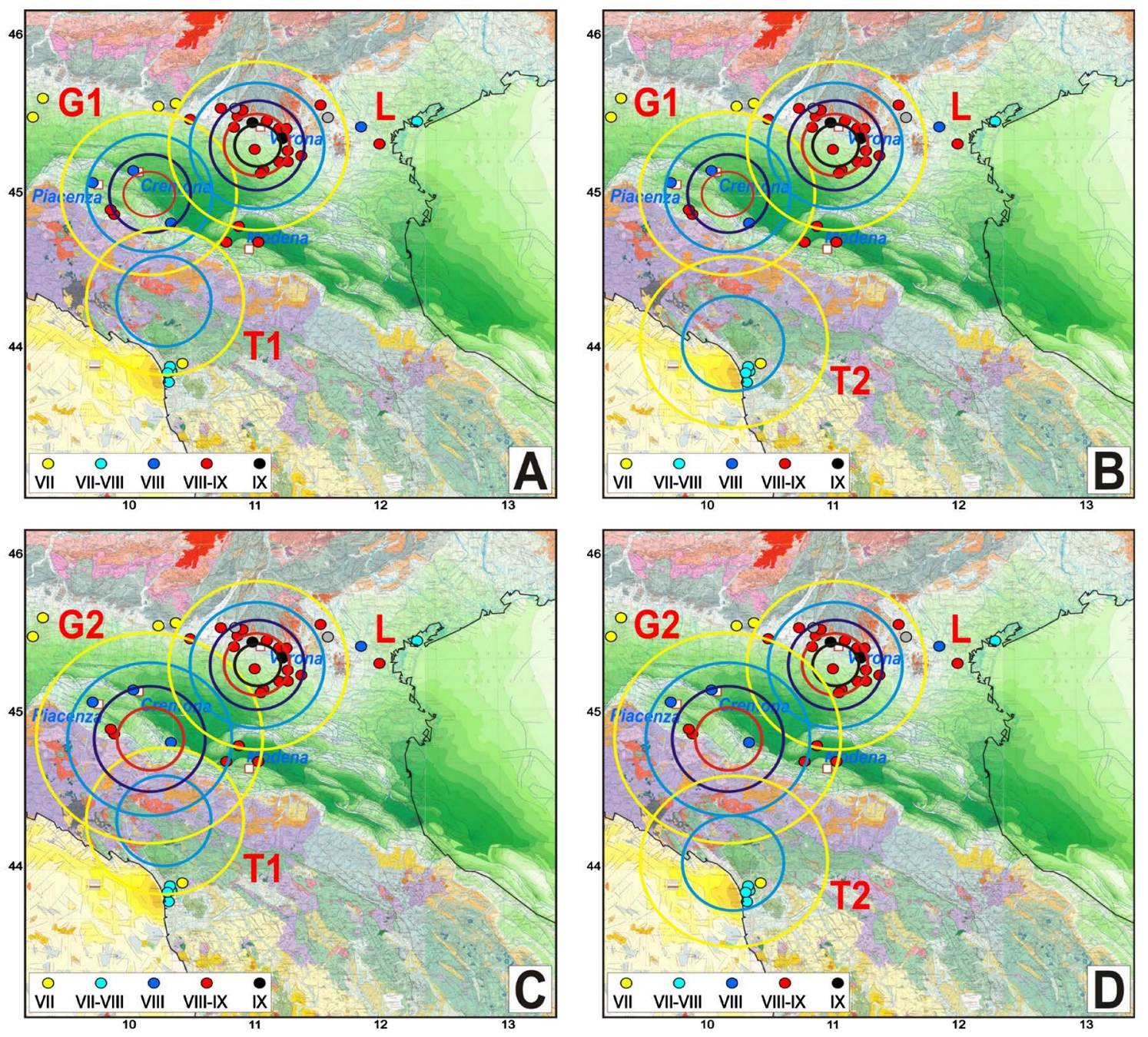

Figure 11. Each picture shows the intensity isolines related to three sources (Figure 10), one located in the Lessini zone, one in the Giudicarie belt (G1 or G2) and one under Northern Tuscany (T1 or T2). The colors of the computed isolines correspond to those of the small colored points at the bottom of each picture, related to the observed intensities (Figure 2). 
of a Lessini fault and two segments of the Giudicarie discontinuity could help to explain what happened in January 2012, when in a few days three significant earthquakes (with focal depths increasing southward) occurred in 3 zones lying fairly close to the sources here proposed (Figure 12). This example may be interesting since it involved a subcrustal earthquake $($ depth $=72 \mathrm{~km})$ beneath northern Tuscany, which is not a very frequent event.

The presence of an additional seismogenic fault located under the Giudicarie belt (for instance the one indicated by G2 in Figure 10) might also help to explain the damage caused by the December 25, 1222 event in the central Po Plain (Figure 13). The macroseismic field documented for that earthquake indicates that the source of most intense damage was in the Brescia zone, as suggested by

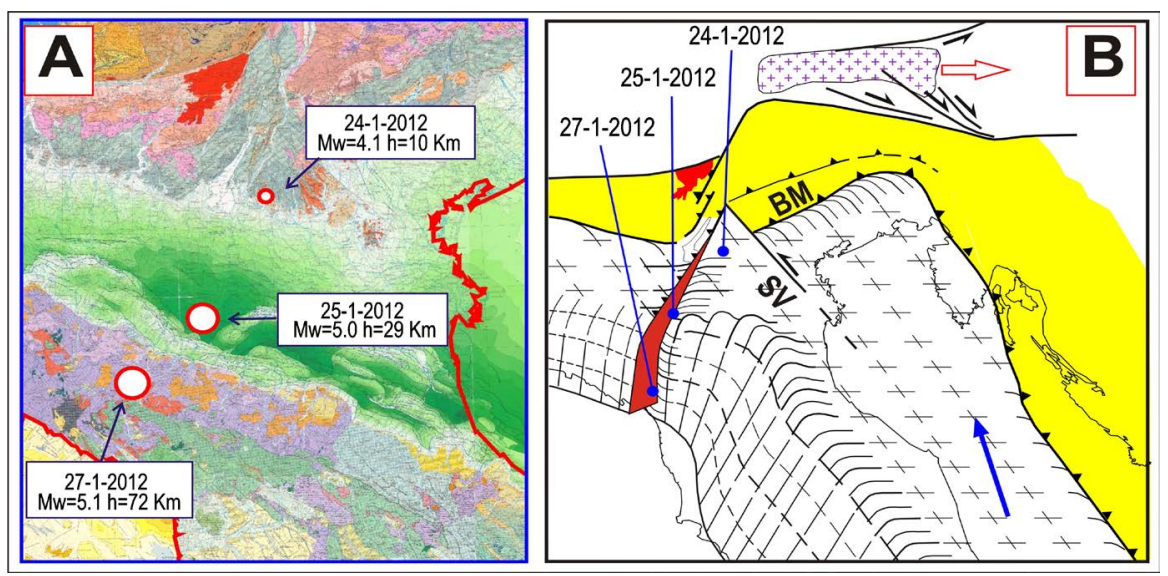

Figure 12. (A) Epicentres of the earthquakes that occurred in the study area on January 2012 [7]. (B) Possible hypocentres of the shocks shown in (A), reported on a tentative perspective view of the Adriatic domain.

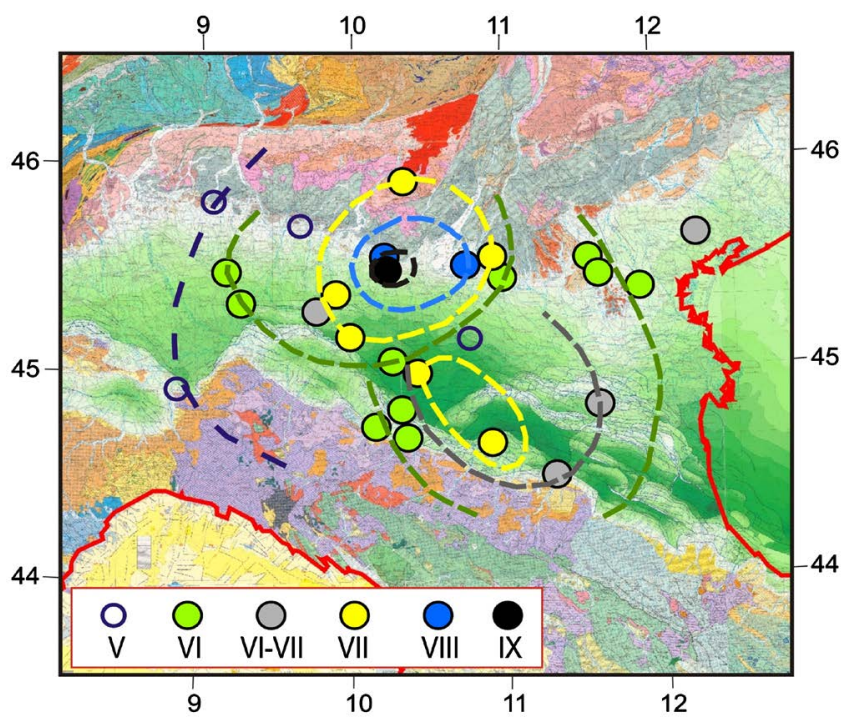

Figure 13. Macroseismic map (coloured circles) of the December 25, 1222 earthquake (Io = IX, [3]). The two sets of isolines tentatively delineate the fields related to one source in the zone of maximum damage (near Brescia) and another possible source in the central Po Plain. 
most authors (e.g., [4] [5]). However, that source cannot easily account for the effects observed in the central Po Plain. The fact that intensities of VI-VII degree were felt at distances greater than $150 \mathrm{~km}$ from the most intense effects (Figure 13) would suggest a non-shallow focal depth for the sources involved.

The tectonic context here proposed implies that the accelerations of the main Adriatic plate, triggered by major earthquakes at the right-lateral (Northern Dinarides), left-lateral (Northern Apennines) and frontal (eastern Southern Alps) boundaries of such plate, may lead to an increase of stress in the zone where the eastern Po Plain Adriatic domain (a portion of the main Adria plate) is bounded by the Lessini structure and the Giudicarie belt (Figure 14). This tectonic connection might involve some correspondences between the most intense seismic phases in the Lessini - Giudicarie zone (1693, 1781-1810, 1866-1904, 1932-1951, 1968-1976, 2003 evidenced by blue bands in Figure 14) and the main seismic periods at the boundaries of the northern Adria domain (1684-1700, 1775-1794, 1873-1895, 1917-1936, 1963-1976, 1998-2004, Figure 14).

\section{Conclusions}

In literature, the genetic mechanism of the most intense documented earthquake in the Po Plain is still surrounded by considerable uncertainty. The sources so far proposed cannot account for the observed macroseismic field, in particular for the damages observed in the central Po Valley area. In this work we suggest that the above problem could be overcome by considering the geodynamic evolution of the northern Adriatic zones, which provides that a major thrust zone has developed beneath the Giudicarie belt since the late Miocene. Here we suggest that the activation of this fault system could have considerably contributed to the 1117 disaster and that the southward deep prolongation of the lithospheric discontinuity lying beneath the Giudicarie belt could have generated the earthquake that produced the damages observed in Tuscany just after the main shock in the Po Valley. The evidence and arguments that can plausibly and coherently support the generation of the Giudicarie transpressional discontinuity in the Upper Miocene and then its evolution in a thrust zone around the late Miocene are extensively described in a number of papers (cited) and synthesized in the first section of this work. In summary, we suggest that the 1117 seismic disaster was caused by the almost coeval activations of three sources. The first was located in the Lessini district, where several transpressional faults are clearly recognized. The second was located beneath the Giudicarie belt, where the eastern Adriatic domain underthrusts the western domain (Figure 7). The coeval effects observed in northern Tuscany are tentatively attributed to the activation of the lithospheric discontinuity that developed beneath the Giudicarie zone in the Upper Miocene (Figure 10 and Figure 11).

The proposed geodynamic setting in the study area implies close tectonic/kinematic connections between the seismic sources cited above, which may help to explain the almost simultaneous activations of such fault zones on January 3 , 

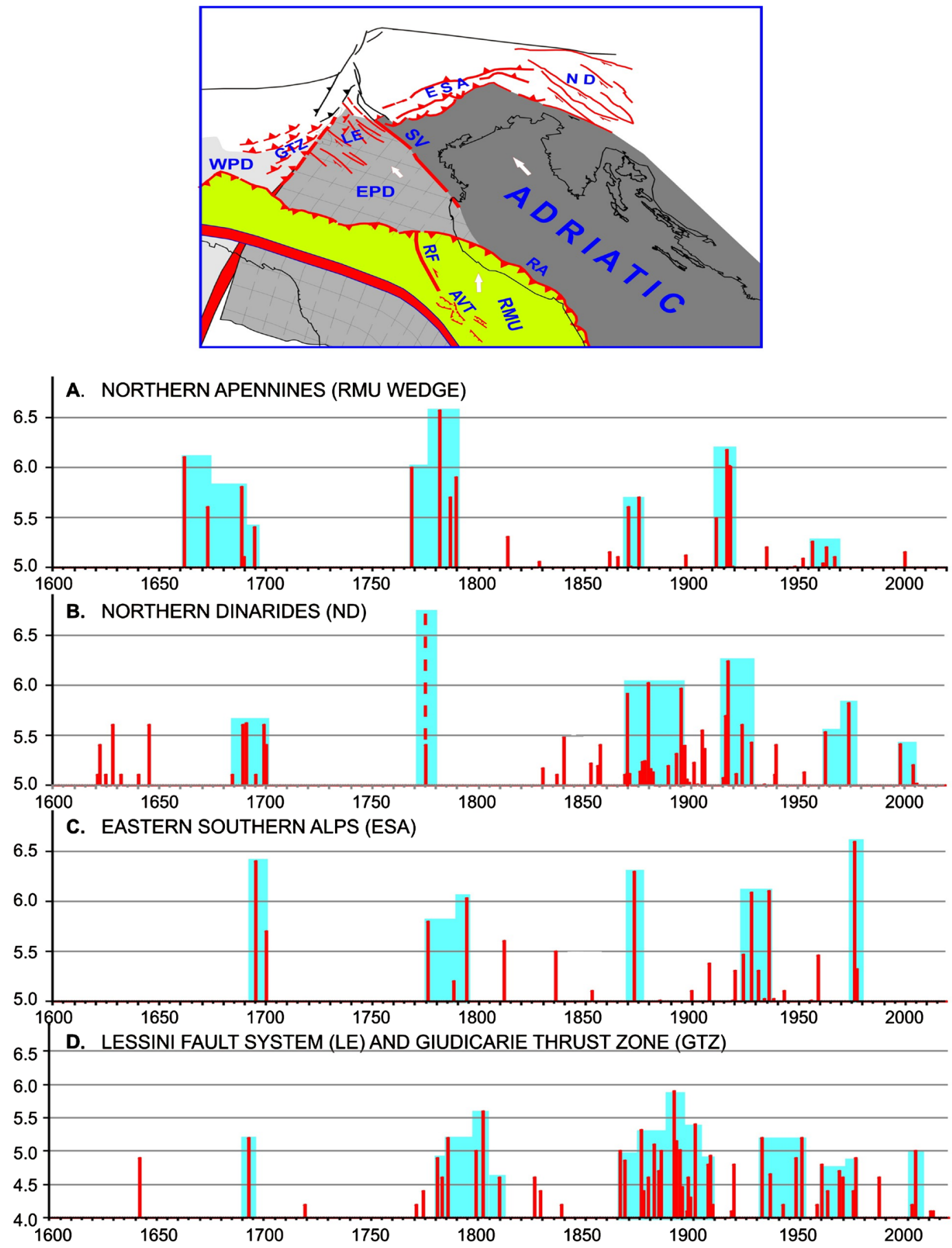

Figure 14. Seismicity patterns (since 1600, [7] [72] [73] [75]) in the tectonic zones that surround the main northern Adriatic domain (A, B, C diagrams) and in the Lessini-Giudicarie zone (D diagram), where the eastern Po Plain domain (EPD) interacts with the western domain (WPD). The main tectonic elements in the zones considered for the diagrams are shown in the map. The decoupling between the Adria plate and the Northern Apennines is allowed by major earthquakes at the boundaries of the Romagna-Marche-Umbria wedge (RMU), as argued in previous works (e.g., [31] [76] [77]). The blue bands highlight the main seismic phases. The dashed bar related to the 1775 earthquake in the northern Dinarides evidences the uncertainty about the magnitude value reported for that event [73] [75]. AVT = Alta Valtiberina trough; ESA = Eastern Southern Alps thrust front; GTZ = Giudicarie thrust zone; LE = Lessini fault system; ND = Northern Dinarides transpressional fault system; RA = Rimini-Ancona front; RF = presumed Romagna fault. 
1117 and the almost simultaneous activations of three similar sources on January 2012 (Figure 12).

The presence of a seismogenetic fault beneath the Giudicarie belt might also help to explain part of the macroseismic field (not compatible with the other sources so far proposed) that was caused by the December 25, 1222 earthquake (Figure 13).

The proposed geodynamic context in the northern Adriatic regions suggests that the occurrence of major earthquakes along the northern front (eastern Southern Alps) and the lateral constraints (Northern Dinarides and Northern Apennines) of the Adria plate may increase stress, in the zones (Lessini and Giudicarie) where the eastern Po Plain domain interacts with the western one. This hypothesis is compatible with the fact that the periods of most intense seismicity in the above zones fairly well correspond to the phases of intense activity at the boundaries of the northern Adria plate (Figure 14).

The seismic history of the Po Plain area [7] indicates that the occurrence of strong earthquakes in the Lessini-Giudicarie fault systems is a very rare event, in line with the expected low velocity of the eastern Po Plain Adriatic domain. The difference between the velocity of the main Adria plate and that of the slower Po Plain domain could be accommodated by an increase of the vertical offset at the Schio-Vicenza fault zone.

\section{Acknowledgements}

We are grateful to an anonymous Reviewer for his very useful suggestions. This work has been financed by the Regione Toscana (Italy).

\section{Conflicts of Interest}

The authors declare no conflicts of interest regarding the publication of this paper.

\section{References}

[1] Magri, G. and Molin, D. (1986) I terremoti del 3 gennaio 1117 e del 25 dicembre 1222, rapporto ENEA. RTIPAS-ISP-GEOL LO, 86.

[2] Galli, P. (2005) I terremoti del gennaio 1117. Ipotesi di un epicentro nel Cremonese. Il Quaternario, 18, 87-100.

[3] Guidoboni, E., Comastri, A. and Boschi, E. (2005) The "Exceptional" Earthquake of 3 January 1117 in the Verona Area (Northern Italy): A Critical Time Review and Detection of Two Lost Earthquakes (Lower Germany and Tuscany). Journal of Geophysical Research, 110, B12309. https://doi.org/10.1029/2005JB003683

[4] Guidoboni, E., Ferrari, G., Mariotti, D., Comastri, A., Tarabusi, G., Sgattoni, G. and Valensise, G. (2018) CFTI5Med, Catalogo dei Forti Terremoti in Italia (461 a.C.-1997) e nell'area Mediterranea (760 a.C.-1500). Istituto Nazionale di Geofisica e Vulcanologia (INGV).

[5] Guidoboni, E. and Comastri, A. (2005) Catalogue of Earthquakes and Tsunamis in the Mediterranean Area from the 11th to the 15th Century. Istituto Nazionale di 
Geofisica e Vulcanologia, Roma.

[6] Locati, M., Camassi, R., Rovida, A., Ercolani, E., Bernardini, F., Castelli, V., Caracciolo, C.H., Tertulliani, A., Rossi, A., Azzaro, R., D’Amico, S., Conte, S., Rocchetti, E. and Antonucci, A. (2019) Database Macrosismico Italiano (DBMI15), Versione 2.0. Istituto Nazionale di Geofisica e Vulcanologia (INGV).

[7] Rovida, A., Locati, M., Camassi, R., Lolli, B. and Gasperini, P. (2019) Catalogo Parametrico dei Terremoti Italiani (CPTI15), versione 2.0. Istituto Nazionale di Geofisica e Vulcanologia (INGV).

[8] Vannoli, P., Burrato, P. and Valensise, G. (2015) The Seismotectonics of the Po Plain (Northern Italy): Tectonic Diversity in a Blind Faulting Domain. Pure and Applied Geophysics, 172, 1105-1142. https://doi.org/10.1007/s00024-014-0873-0

[9] DISS Working Group (2018) Database of Individual Seismogenic Sources (DISS), Version 3.2.1: A Compilation of Potential Sources for Earthquakes Larger than $M$ 5.5 in Italy and Surrounding Areas. Istituto Nazionale di Geofisica e Vulcanologia (INGV).

[10] Burrato, P., Ciucci, F. and Valensise, G. (2003) An Inventory of River Anomalies in the Po Plain, Northern Italy: Evidence for Active Blind Thrust Faulting. Annals of Geophysics, 46, 865-882.

[11] Viti, M., Mantovani, E., Babbucci, D., Tamburelli, C. and Cenni, N. (2016) Seismotectonics of the Padanian Region and Surrounding Belts: Which Driving Mechanism? International Journal of Geosciences, 7, 1412-1451.

https://doi.org/10.4236/ijg.2016.712100

[12] Slejko, D., Carulli, G.B., Nicolich, R., Rebez, A., Zanferrari, A., Cavallin, A., Doglioni, C., Carraro, F., Castaldini, D., Iliceto, V., Semenza, E. and Zanolla, C. (1989) Seismotectonics of the Eastern Southern-Alps: A Review. Bollettino di Geofisica Teorica ed Applicata, 31, 109-136.

[13] Bigi, G., Cosentino, D., Parotto, M., Sartori, R. and Scandone, P. (1990) Structural Model of Italy, 1:500000, CNR, Progetto Finalizzato Geodinamica. Selca, Firenze.

[14] Castellarin, A., Vai, G.B. and Cantelli, L. (2006) The Alpine Evolution of the Southern Alps around the Giudicarie Faults: A Late Cretaceous to Early Eocene Transfer Zone. Tectonophysics, 414, 203-223. https://doi.org/10.1016/j.tecto.2005.10.019

[15] Scardia, G., Festa, A., Monegato, G., Pini, R., Rogledi, S., Tremolada, F. and Galadini, F. (2015) Evidence for Late Alpine Tectonics in the Lake Garda Area (Northern Italy) and Seismogenic Implications. GSA Bulletin, 127, 113-130.

https://doi.org/10.1130/B30990.1

[16] Turrini, C., Bisica, B., Ryan, P., Shiner, P., Lacombe, O. and Roure, F. (2018) 3D Structural and Thermal Modeling of Mesozoic Petroleum System in the Po Valley, Northern Italy. Petroleum Geoscience, 24, 172-196.

https://doi.org/10.1144/petgeo2017-031

[17] Brancolini, G., Civile, D., Donda, F., Tosi, L., Zecchin, M., Volpi, V., Rossi, G., Sandron, D., Matilde Ferrante, G. and Forlin, E. (2019) New Insights on the Adria Plate Geodynamics from the Northern Adriatic Perspective. Marine and Petroleum Geology, 109, 687-697. https://doi.org/10.1016/j.marpetgeo.2019.06.049

[18] Galadini, F., Galli, P., Cittadini, A. and Giaccio, B. (2001) Late Quaternary Fault Movements in the Mt. Baldo-Lessini Mts. Sector of the SoutAlpine Area (Northern Italy). Netherlands Journal of Geosciences, 80, 187-208. https://doi.org/10.1017/S0016774600023830

[19] Galadini, F., Poli, M.E. and Zanferrari, A. (2005) Seismogenic Sources Potentially 
Responsible for Earthquakes with $\mathrm{M} \geq 6$ in the Eastern Southern Alps (Thiene-Udine Sector, NE Italy). Geophysical Journal International, 161, 739-762. https://doi.org/10.1111/j.1365-246X.2005.02571.x

[20] Rogledi, S. (2010) Assetto strutturale delle unità alpine nella pianura tra il lago d'Iseo e il Garda. Presentazione al Convegno "Rischio sismico nella Pianura Padana", Museo Civico di Scienze Naturali, Brescia, 24 Novembre 2010. http://ingegneriasismica.org/it/structural-setting-of-the-central-po-plain

[21] Galadini, F. and Galli, P. (2001) Archaeoseismology in Italy: Case Studies and Implications on Long-Term Seismicity. Journal of Earthquake Engineering, 5, 35-68. https://doi.org/10.1080/13632460109350385

[22] Sugan, M. and Peruzza, L. (2011) Distretti sismici del Veneto. Bollettino di Geofisica Teorica ed Applicata, 52, s3-s90.

[23] Zanferrari, A., Bollettinari, G., Carobene, L., Carton, A., Carulli, G.B., Castaldini, D., Cavallin, A., Panizza, M., Pellegrini, G.B., Pianetti, F. and Sauro, U. (1982) Evoluzione neotettonica dell'Italia nord-orientale. Memorie di Scienze Geologiche, 35, 355-376.

[24] Zampieri, D. (2000) Segmentation and Linkage of the Lessini Mountains Normal Faults, Southern Alps, Italy. Tectonophysics, 319, 19-31. https://doi.org/10.1016/S0040-1951(00)00025-1

[25] Viganò, A., Bressan, G., Ranalli, G. and Martin, S. (2008) Focal Mechanism Inversion in the Giudicarie-Lessini Seismotectonic Region (Southern Alps, Italy): Insights on Tectonic Stress and Strain. Tectonophysics, 460, 106-115. https://doi.org/10.1016/j.tecto.2008.07.008

[26] Sauro, U. and Zampieri, D. (2001) Evidence of Recent Surface Faulting and Surface Rupture in the Fore-Alps of Veneto and Trentino (NE Italy). Geomorph, 40, 169-184. https://doi.org/10.1016/S0169-555X(01)00041-1

[27] Viganò, A., Scafidi, D., Ranalli, G., Martin, S., Della Vedova, B. and Spallarossa, D. (2015) Earthquake Relocations, Crustal Rheology, and Active Deformation in the Central-Eastern Alps (N Italy). Tectonophysics, 661, 81-98. https://doi.org/10.1016/j.tecto.2015.08.017

[28] Maesano, F.E. and D'Ambrogi, C. (2016) Coupling Sedimentation and Tectonic Control: Pleistocene Evolution of the Central Po Basin. Italian Journal of Geosciences, 135, 394-407. https://doi.org/10.3301/IJG.2015.17

[29] Maesano, F.E., D’Ambrogi, C., Burrato, P. and Toscani, G. (2015) Slip-Rates of blind Thrusts in Slow Deforming Areas: Examples from the Po Plain (Italy). Tectonophysics, 643, 8-25. https://doi.org/10.1016/j.tecto.2014.12.007

[30] Mantovani, E., Babbucci, D., Tamburelli, C. and Viti, M. (2009) A Review on the Driving Mechanism of the Tyrrhenian-Apennines System: Implications for the Present Seismotectonic Setting in the Central-Northern Apennines. Tectonophysics, 476, 22-40. https://doi.org/10.1016/j.tecto.2008.10.032

[31] Mantovani, E., Viti, M., Babbucci D., Tamburelli, C. and Cenni, N. (2019) How and Why the Present Tectonic Setting in the Apennine Belt Has Developed. Journal of the Geological Society of London, 176, 1291-1302. https://doi.org/10.1144/jgs2018-175

[32] Mantovani, E., Viti, M., Babbucci, D., Tamburelli, C. and Cenni, N. (2020) Geodynamics of the Central Western Mediterranean Region: Plausible and Non-Plausible Driving Forces. Marine and Petroleum Geology, 113, Article ID: 104121. https://doi.org/10.1016/j.marpetgeo.2019.104121 
[33] Castellarin, A., Cantelli, L., Fesce, A.M., Mercier, J.L., Picotti, V., Pini, G.A., Prosser, G. and Selli, L. (1992) Alpine Compressional Tectonics in the Southern Alps. Relationships with the N. Apennines. Annales Tectonicae, 6, 62-94.

[34] Castellarin, A. and Cantelli, L. (2000) Neo-Alpine Evolution of the Southern Eastern Alps. Journal of Geodynamics, 30, 251-274.

https://doi.org/10.1016/S0264-3707(99)00036-8

[35] Doglioni, C. and Bosellini, A. (1987) Eoalpine and Mesoalpine Tectonics in the Southern Alps. Geologische Rundschau, 76, 735-754. https://doi.org/10.1007/BF01821061

[36] Martin, S., Bigazzi, G., Zattin, M., Viola, G. and Balestrieri, M.L. (1998) Neogene Kinematics of the Giudicarie Fault (Central-Eastern Alps, Italy): New Apatite Fission-Track Data. Terra Nova, 10, 217-221. https://doi.org/10.1046/j.1365-3121.1998.00119.x

[37] Frisch, W., Dunkl, I. and Kuhlemann, J. (2000) Post-Collisional Orogen-Parallel Large-Scale Extension in the Eastern Alps. Tectonophysics, 327, 239-265. https://doi.org/10.1016/S0040-1951(00)00204-3

[38] Zampieri, D., Massironi, M., Sedea, R. and Saracino, V. (2003) Strike-Slip Contractional Stepovers in the Southern Alps (Northeastern Italy). Eclogae Geologicae Helvetiae, 96, 115-123.

[39] Massironi, M., Zampieri, D. and Caporali, A. (2006) Miocene to Present Major Fault Linkages through the Adriatic Indenter and the Austroalpine-Penninic Collisional Wedge (Alps of NE Italy). Geological Society, London, Special Publications, 262, 245-258. https://doi.org/10.1144/GSL.SP.2006.262.01.15

[40] Pola, M., Ricciato, A., Fantoni, R., Fabbri, P. and Zampieri, D. (2014) Architecture of the Western Margin of the North Adriatic Foreland: The Schio-Vicenza Fault System. Italian Journal of Geosciences, 133, 223-234. https://doi.org/10.3301/IJG.2014.04

[41] Mantovani, E., Viti, M., Babbucci, D., Tamburelli, C., Cenni, N., Baglione, M. and D'Intinosante, V. (2014) Generation of Back-Arc Basins as Side Effect of Shortening Processes: Examples from the Central Mediterranean. International Journal of Geosciences, 5, 1062-1079. https://doi.org/10.4236/ijg.2014.410091

[42] Mantovani, E., Viti, M., Babbucci, D., Tamburelli, C. and Albarello, D. (2006) Geodynamic Connection between the Indentation of Arabia and the Neogene Tectonics of the Central-Eastern Mediterranean Region. In: Dilek, Y. and Pavlides, S., Eds., Post-Collisional Tectonics and Magmatism in the Mediterranean Region and Asia, Geological Society of America Special Papers 409, Boulder, 15-41. https://doi.org/10.1130/2006.2409(02)

[43] Mantovani, E., Viti, M., Cenni, N., Babbucci, D. and Tamburelli, C. (2015) Present Velocity Field in the Italian Region by GPS Data: Geodynamic/Tectonic Implications. International Journal of Geosciences, 6, 1285-1316. https://doi.org/10.4236/ijg.2015.612103

[44] Viti, M., Mantovani, E., Babbucci, D. and Tamburelli, C. (2006) Quaternary Geodynamics and Deformation Pattern in the Southern Apennines: Implications for Seismic Activity. Bollettino del Servizio geologico d Italia, 125, 273-291.

[45] Viti, M., Mantovani, E., Babbucci, D. and Tamburelli, C. (2011) Plate Kinematics and Geodynamics in the Central Mediterranean. Journal of Geodynamics, 51, 190-204. https://doi.org/10.1016/j.jog.2010.02.006

[46] Finetti, I.R. (2005) Crustal Tectono-Stratigraphic Sections across the Western and Eastern Alps from ECORS-CROP and Transalp Seismic Data. In: Finetti, I.R., Ed., 
CROP Project. Deep Seismic Exploration of the Central Mediterranean and Italy, Elsevier, Amsterdam, 109-118

[47] Molnar, P. and Lyon-Caen, H. (1988) Some Simple Physical Aspects of the Support, Structure and Evolution of Mountain Belts. In: Clark, S.P., Ed., Processes in Continental Lithospheric Deformation, Geological Society of America Special Papers 218, Boulder, 179-207. https://doi.org/10.1130/SPE218-p179

[48] Seghedi, I., Downes, H., Szakács, A., Mason, P.R.D., Thirlwall, M.F., Rosu, E., Pécskay, Z., Márton, E. and Panaiotu, C. (2004) Neogene Quaternary Magmatism and Geodynamics in the Carpathian-Pannonian Region: A Synthesis. Lithos, 72, 117-146. https://doi.org/10.1016/j.lithos.2003.08.006

[49] Mantovani, E. (2005) Evolutionary Reconstruction of the Mediterranean Region: Extrusion Tectonics driven by Plate Convergence. In: Finetti, I.R., Ed., CROP PROJECT: Deep Seismic Exploration of the Central Mediterranean and Italy, Elsevier, Amsterdam, 705-746.

[50] Mantovani, E., Viti, M., Babbucci, D. and Albarello, D. (2007) Nubia-Eurasia Kinematics: An Alternative Interpretation from Mediterranean and North Atlantic Evidence. Annals of Geophysics, 50, 311-336.

[51] Ratschbacher, L., Merle, O., Davy, P. and Cobbold, P. (1991) Lateral Extrusion in the Eastern Alps, Part I: Boundary Conditions and Experiments Scaled for Gravity. Tectonics, 10, 245-256.

[52] Ratschbacher, L., Frisch, W., Linzer, H.G. and Merle, O. (1991) Lateral Extrusion in the Eastern Alps, Part 2: Structural Analysis. Tectonics, 10, 257-271.

https://doi.org/10.1029/90TC02623

[53] Picotti, V., Prosser, G. and Castellarin, A. (1995) Structures and Kinematics of the Giudicarie-Val Trompia Fold and Thrust Belt (Central Southern Alps, Northern Italy). Memorie di Scienze Geologiche, 47, 95-109.

[54] Picotti, V., Casolari, E., Castellarin, A., Mosconi, A., Cairo, E., Pessina, C. and Sella, M. (1997) Alpine Inversion of Mesozoic Rift Basin: The Case of the Eastern Lombardian Prealps. Universita'di Bologna-AGIP, Centro Stampa AGIP S.p.A. (S. Donato Milanese).

[55] Viola, G., Mancktelow, N.S. and Seward, D. (2001) Late Oligocene-Neogene Evolution of Europe-Adria Collision: New Structural and Geochronological Evidence from the Giudicarie Fault System (Italian Eastern Alps). Tectonics, 20, 999-1020. https://doi.org/10.1029/2001TC900021

[56] Livio, F.A., Berlusconi, A., Michetti, A.M., Sileo, G., Zerboni, A., Trombino, L., Cremaschi, M., Mueller, K., Vittori, E., Carcano, C. and Rogledi, S. (2009) Active Fault-Related Folding in the Epicentral Area of the December 25, 1222 (Io = IX MCS) Brescia Earthquake (Northern Italy): Seismotectonic Implications. Tectonophysics, 476, 320-335. https://doi.org/10.1016/j.tecto.2009.03.019

[57] Reverman, R.L., Fellin, M.G., Herman, F., Willett, S.D. and Fitoussi, C. (2012) Climatically versus Tectonically Forced Erosion in the Alps: Thermochronometric Constraints from the Adamello Complex, Southern Alps, Italy. Earth and Planetary Science Letters, 339-340, 127-138. https://doi.org/10.1016/j.epsl.2012.04.051

[58] Cuffaro, M., Riguzzi, F., Scrocca, D., Antonioli, F., Carminati, E., Divani, M. and Doglioni, C. (2010) On the Geodynamics of the Northern Adriatic Plate. Rendiconti Lincei. Scienze Fisiche e Naturali, 21, 253-279. https://doi.org/10.1007/s12210-010-0098-9

[59] Turrini, C., Lacombe, O. and Roure, F. (2014) Present-Day 3D Structural Model of the Po Valley Basin, Northern Italy. Marine and Petroleum Geology, 56, 266-289. 
https://doi.org/10.1016/j.marpetgeo.2014.02.006

[60] Turrini, C., Angeloni, P., Lacombe, O., Ponton, M. and Roure, F. (2015) Three-Dimensional Seismo-Tectonics in the Po Valley Basin, Northern Italy. Tectonophysics, 661, 156-179. https://doi.org/10.1016/j.tecto.2015.08.033

[61] Zampieri, D. (1995) Tertiary Extension in the Southern Trento Platfotm, Southern Alps. Tectonics, 14, 645-657. https://doi.org/10.1029/94TC03093

[62] Fantoni, R. and Franciosi, R. (2010) Tectono-Sedimentary Setting of the Po Plain and Adriatic Foreland. Rendiconti Lincei. Scienze Fisiche e Naturali, 21, 197-209. https://doi.org/10.1007/s12210-010-0102-4

[63] Castellarin, A., Fesce, A.M., Picotti, V., Pini, G.A., Prosser, G., Sartori, R., Selli, L., Cantelli, L. and Ricci, R. (1988) Structural and Kinematics Analysis of the Giudicarie Deformation Belt. Implications for Compression Tectonics of Southern Alps. Mineralogica Petrographica Acta, 30, 287-310.

[64] Fantoni, R. and Franciosi, R. (2009) Estensione mesozoica e compressione cenozoica nell'avampaese padano-adriatico. Abstract e Poster Natura e geodinamica della litosfera nell'alto Adriatico. Rendiconti online della Società Geologica Italiana, 9, 28-31.

[65] Arca, S. and Berretta, G.P. (1985) Prima sintesi geodetica e geologica sui movimenti verticali del suolo nell'Italia Settentrionale. Bollettino di Geodesia e Scienze Affini, 44, 125-156.

[66] Mantovani, E., Viti, M., Babbucci, D., Cenni, N., Tamburelli, C., Vannucchi, A., Falciani, F., Fianchisti, G., Baglione, M., D’Intinosante, V., Fabbroni, P., Martelli, L., Baldi, P. and Bacchetti, M. (2013) Assetto tettonico e potenzialità sismogenetica dell'Appennino Tosco Romagnolo e Val Padana.

https://ambiente.regione.emilia-romagna.it/it/geologia/pubblicazioni/libri https://www.regione.toscana.it/-/pubblicazioni-11

[67] Cenni, N., Mantovani, E., Baldi, P. and Viti, M. (2012) Present Kinematics of Central and Northern Italy from Continuous GPS Measurements. Journal of Geodynamics, 58, 62-72. https://doi.org/10.1016/j.jog.2012.02.004

[68] Cenni, N., Viti, M., Baldi, P., Mantovani, E., Bacchetti, M. and Vannucchi, A. (2013) Present Vertical Movements in Central and Northern Italy from GPS Data: Possible Role of Natural and Anthropogenic Causes. Journal of Geodynamics, 71, 74-85. https://doi.org/10.1016/j.jog.2013.07.004

[69] Carminati, E., Doglioni, C. and Scrocca, D. (2005) Magnitude and Causes of Long-Term Subsidences of the Po Plain and Venetian Region. In: Fletcher, C.A., Spencer, T., with Da Mosto, J. and Campostrini, P., Eds., Flooding and Environmental Challenges for Venice and Its Lagoon: State of Knowledge, Cambridge University Press, Cambridge, 21-28.

[70] Giambastiani, B.M.S., Antonellini, M., Oude Essink, G.H.P. and Stuurman, R.J. (2007) Salt Water Intrusion in the Unconfined Coastal Aquifer of Ravenna (Italy): A Numerical Model. Journal of Hydrology, 340, 94-104. https://doi.org/10.1016/j.jhydrol.2007.04.001

[71] Teatini, P., Tosi, L. and Strozzi, T. (2011) Quantitative Evidence That Compaction of Holocene Sediments Drives the Present Land Subsidence of the Po Delta, Italy. Journal of Geophysical Research, 116, B08407. https://doi.org/10.1029/2010JB008122

[72] Stucchi, M., Rovida, A., Gomez Capera, A.A., Alexandre, P., Camelbeeck, T., Demircioglu, M.B., Gasperini, P., Kouskouna, V., Musson, R.M.W., Radulian, M., Sesetyan, K., Vilanova, S., Baumont, D., Bungum, H., Fäh, D., Lenhardt, W., Makro- 
poulos, K., Martinez Solares, J.M., Scotti, O., Zivcic, M., Albini, P., Batllo, J., Papaioannou, C., Tatevossian, R., Locati, M., Meletti, C., Viganò, D. and Giardini, D. (2012) The SHARE European Earthquake Catalogue (SHEEC) 1000-1899. Journal of Seismology, 17, 523-544. https://doi.org/10.1007/s10950-012-9335-2

[73] Grünthal, G. and Wahlström, R. (2012) The European-Mediterranean Earthquake Catalogue (EMEC) for the Last Millennium. Journal of Seismology, 16, 535-557. https://doi.org/10.1007/s10950-012-9302-y

[74] Decanini, L.D. and Mollaioli, F. (1997) Sull'attenuazione dell'intensità macrosismica in alcune zone sismogenetiche italiane, VIII Convegno Nazionale: L'ingegneria sismica in Italia, Taormina, 21-24 settembre 1997, 2: 895-902. Palermo, Priulla.

[75] Shebalin, N.V., Karnik, V. and Hadzievski, D. (1974) UNDP-Unesco Survey of the Seismicity of Balkan Region. Catalogue of Earthquakes, Part I, 1901-70, Skopje.

[76] Mantovani, E., Viti, M., Cenni, N., Babbucci, D., Tamburelli, C., Baglione, M. and D'Intinosante, V. (2015) Seismotectonics and Present Seismic Hazard in the Tuscany-Romagna-Marche-Umbria Apennines (Italy). Journal of Geodynamics, 89, 1-14. https://asbproxy.unisi.it:2731/10.1016/j.jog.2015.05.001 https://doi.org/10.1016/j.jog.2015.05.001

[77] Mantovani, E., Viti, M., Babbucci, D., Tamburelli, C., Cenni, N., Baglione, M. and D'Intinosante, V. (2016) Recognition of Peri-Adriatic Seismic Zones Most Prone to Next Major Earthquakes: Insights from a Deterministic Approach. In: D’Amico, S., Ed., Earthquakes and Their Impact on Society, Springer Natural Hazard, Springer International Publishing, Berlin, 43-80.

https://doi.org/10.1007/978-3-319-21753-6_2 